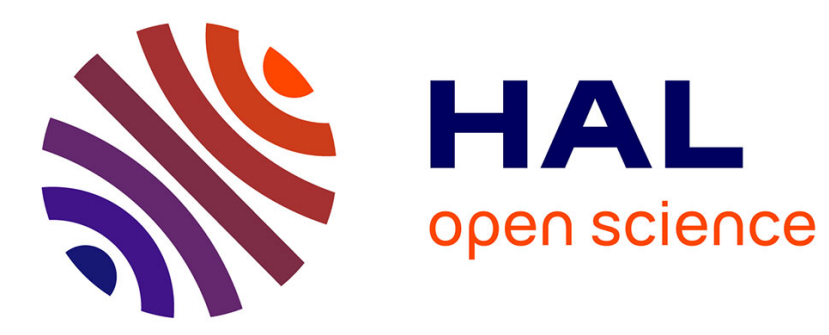

\title{
Solvent-free synthesis of unsaturated amino esters in a ball-mill
}

\author{
Alice Baron, Jean Martinez, Frederic Lamaty
}

\section{To cite this version:}

Alice Baron, Jean Martinez, Frederic Lamaty. Solvent-free synthesis of unsaturated amino esters in a ball-mill. Tetrahedron Letters, 2010, 51, pp.6246-6249. 10.1016/j.tetlet.2010.09.069 . hal-03118824

\section{HAL Id: hal-03118824 \\ https://hal.science/hal-03118824}

Submitted on 22 Jan 2021

HAL is a multi-disciplinary open access archive for the deposit and dissemination of scientific research documents, whether they are published or not. The documents may come from teaching and research institutions in France or abroad, or from public or private research centers.
L'archive ouverte pluridisciplinaire HAL, est destinée au dépôt et à la diffusion de documents scientifiques de niveau recherche, publiés ou non, émanant des établissements d'enseignement et de recherche français ou étrangers, des laboratoires publics ou privés. 


\title{
Solvent-free synthesis of unsaturated amino esters in a ball-mill
}

\author{
Alice Baron, Jean Martinez, Frédéric Lamaty* \\ Institut des Biomolécules Max Mousseron UMR 5247 CNRS-Université Montpellier 1 et Université Montpellier 2, Place Eugène Bataillon, 34095 Montpellier cedex 05, France
}

\begin{abstract}
A B S T R A C T
The ball-milling technique was used under solvent-free conditions to perform a Horner-WadsworthEmmons reaction in the presence of a mild carbonate base. Starting from a phosphonate-substituted glycine, this method gave access to Boc-protected unsaturated amino esters in excellent yield and selectivity in many cases. The scope of the reaction was delineated.
\end{abstract}

\author{
Keywords: \\ Ball-mill \\ Solvent-free \\ Amino acid \\ Horner-Wadsworth-Emmons \\ Olefination \\ Dehydroalanine \\ Carbonate base \\ Phosphonate
}

Ball-milling is a mechanochemical technique that is widely applied to the grinding of minerals into fine particles, to the preparation, and modification of inorganic solids. ${ }^{1,2}$ Ball-mill chemistry is of interest because it is performed in the absence of solvent, under environmentally friendly conditions. In the last years, this technique has found interest in synthetic organic chemistry. ${ }^{3,4}$ The reported examples include nitrone synthesis, ${ }^{5}$ functionalization of fullerenes, ${ }^{6}$ reductive benzylation of malonitrile, ${ }^{7}$ protection of amines, ${ }^{8}$ Knoevenagel reaction, ${ }^{9}$ aldol condensation ${ }^{10}$ and its asymmetric version, ${ }^{11}$ Michael additions, ${ }^{9}$ preparation of phosphorus ylides, ${ }^{12}$ oxidative coupling of 2 -naphthol, ${ }^{13}$ Heck, ${ }^{14}$ Suzuki ${ }^{15}$ and Sonogashira ${ }^{16}$ coupling reactions, and peptide synthesis. ${ }^{17}$

One powerful method for making carbon-carbon bond is the Wittig reaction starting from carbonyl compounds and making use of a phosphorus ylide. ${ }^{18}$ It was shown recently that this reaction could be performed in a ball-mill ${ }^{12}$ (scheme 1 ).

The Horner-Wadsworth-Emmons (HWE) version ${ }^{19}$ of the Wittig reaction focuses on the use of more stabilized phosphonate ylides. This is a method of choice for the preparation of unsaturated esters ( $E W G=\mathrm{CO}_{2} \mathrm{R}$ ). Usually, the phosphonate stabilized carbanion is sufficiently nucleophilic to react under mild conditions to yield the olefin. As part of our program to prepare unnatural amino acids and use them as building blocks for peptide synthesis, ${ }^{20}$ we considered the development of a HWE reaction in a ball-mill as a valuable route for the synthesis of unsaturated ami-

\footnotetext{
* Corresponding author. Tel.: +33 467143847; fax: +33 467144866.

E-mail address: frederic.lamaty@univ-montp2.fr (F. Lamaty).
}

no esters. ${ }^{21}$ The synthesis developed by Schmidt et al.,22 based on the HWE reaction, is a practical method for making olefinic amino esters from a carbonyl compound and a phosphonate derivative of glycine (scheme 2). Nevertheless, it requires usually the use of an excess of organic base and a low temperature for the deprotonation step is needed.

Few examples of solvent-free HWE reactions have been published but very often an excess of liquid reactant serves as the solvent. ${ }^{23 a-c}$ Since the Wittig reaction has been explored under mechanical activation, ${ }^{12}$ we presumed that the HWE version could be a viable and powerful approach for the preparation of unsaturated amino esters starting from carbonyl compounds.

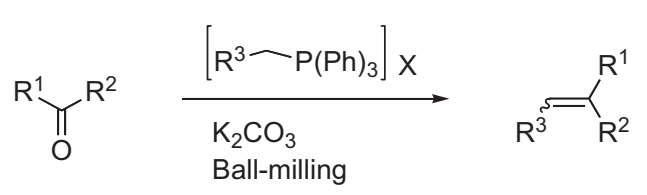

Scheme 1. Solvent-free Wittig reaction in a ball-mill.

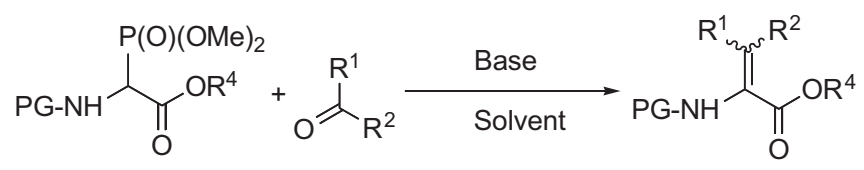

Scheme 2. Horner-Wadsworth-Emmons reaction 
Table 1

Reaction conditions for the HWE reaction in a ball-mill ${ }^{\mathrm{a}}$<smiles>COC(=O)C(=Cc1cc(OC)cc(OC)c1)NC(=O)C(C)(C)C</smiles>

\begin{tabular}{|c|c|c|c|}
\hline Entry & Base (equiv) & Conversion (\%) & Yield (\%) \\
\hline 1 & $\mathrm{NaHCO}_{3}(3)$ & 5 & n.d. ${ }^{\mathrm{c}}$ \\
\hline 2 & $\mathrm{~K}_{2} \mathrm{CO}_{3}(1)$ & 91 & n.d. \\
\hline 3 & $\mathrm{~K}_{2} \mathrm{CO}_{3}(3)$ & 93 & n.d. \\
\hline 4 & $\mathrm{KOH}(3)$ & $94^{\mathrm{b}}$ & n.d. \\
\hline 5 & $\mathrm{Cs}_{2} \mathrm{CO}_{3}(3)$ & 100 & 95 \\
\hline 6 & $\mathrm{Cs}_{2} \mathrm{CO}_{3}(2)$ & 100 & 94 \\
\hline 7 & $\mathrm{Cs}_{2} \mathrm{CO}_{3}(1.5)$ & 94 & n.d. \\
\hline 8 & DBU & 63 & n.d. \\
\hline
\end{tabular}

a Starting materials were ground in a planetary ball-mill for $7 \mathrm{~h}$.

b Hydrolysis product 4a was also obtained.

c n.d.: not determined.

Reactions in a ball-mill give better results when solid-solid reactions are performed. ${ }^{8}$ Therefore, starting from solid aminophosphoryl acetate, we tested the reaction on a solid aldehyde, 3,5-dimethoxybenzaldehyde, and a solid carbonate base. A mixture of aminophosphoryl acetate 1 (1.1 equiv), 3,5-dimethoxybenzaldehyde 2a (1 equiv) and a base (1-3 equiv) was ground in a planetary ball-mill. In order to reduce the purification steps, a conversion close or equal to $100 \%$ was needed. The reaction mixture was analyzed by HPLC to evaluate the conversion of the starting materials and the formation of the expected product. Results are summarized in Table 1. Generally, reaction time inferior to $7 \mathrm{~h}$ led to incomplete conversion. Sodium bicarbonate gave a very low conversion (entry 1 ). Potassium carbonate (entry 2) gave a good conversion albeit not total even if the number of equivalents was increased (entry 3 ). In those cases, the HWE reaction product 3a was obtained. ${ }^{24}$ This was actually not the case for the reaction with potassium hydroxide (entry 4). The reaction was not very clean and the major product, along with some starting material and expected $\mathbf{3 a}$, was $\mathbf{4 a}$ arising from the concomitant saponification of 3a. The best results were obtained with cesium carbonate (entries 5-7). The initial amount of base ( 3 equiv) could be lowered to 2 equiv but not further (entry 7). In these cases, the expected product 3a was obtained, in good yield when the conversion was complete. Finally, DBU that is the common base use in the Schmidt route was also tested (entry 8 ) but yielded a limited conversion. For the sake of comparison, the reaction was carried out in a flask with a stir bar using the conditions from entry 6 (cesium carbonate as a base). In the absence of heating, an incomplete conversion (43\%) was obtained. This was not improved by heating to $50{ }^{\circ} \mathrm{C}$ since only $45 \%$ conversion was obtained, showing the importance of mechanical activation in this reaction.

When the conversion was complete, a work up using a minimum amount of solvent was performed. Ethyl acetate was added and the solution was washed with water, dried, evaporated and filtered on a silica gel pad to give amino ester 3a with an excellent purity and yield. ${ }^{25}$ In this reaction, only one isomer was obtained and characterized by ${ }^{1} \mathrm{H}$ and ${ }^{13} \mathrm{C}$ NMR. In contrast to the Wittig reaction in a ball-mill, ${ }^{12}$ the stereochemical outcome of the reaction in the ball-mill is the same as in solution. Only the $Z$ isomer could be detected by NMR.
To investigate the scope of the reaction with various aldehydes and ketones, we considered their reactions in the presence of $\mathrm{Cs}_{2} \mathrm{CO}_{3}$ or $\mathrm{K}_{2} \mathrm{CO}_{3}$. $\mathrm{Cs}_{2} \mathrm{CO}_{3}$ was considered as the best base but since $\mathrm{K}_{2} \mathrm{CO}_{3}$ gave satisfactory results, it was also tested because of its superiority from an economical, ecological, and toxicological point of view. Eventually, it proved even superior to $\mathrm{Cs}_{2} \mathrm{CO}_{3}$ in many cases. The preparation of various protected amino esters is presented in Table 2 .

Generally, aromatic aldehydes (entries 1-6) reacted efficiently with complete conversion in most of the cases. Even a hindered ortho-substituted aryl aldehyde, such as $\mathbf{2 b}$ (entry 2) gave an excellent result. For this series, the $Z / E$ selectivity was very high since only the $Z$ isomer could be detected, except in the case of naphthaldehyde $\mathbf{2 f}$ (entry 6 ) where the proportion is in favor of the same isomer but with a lower selectivity. Even if reaction conditions were tested on the formation of $\mathbf{3 a}$, starting from solid aldehyde 2a (entry 1), liquid aldehydes also gave satisfying results (entries 3-6). Among the aliphatic aldehydes (entries 710), $n$-butyraldehyde $\mathbf{2 g}$, a linear aldehyde, gave the best results in term of yields and selectivity (entry 7). Conversions of monosubstituted methanals $\mathbf{2 h}$ and $\mathbf{2 i}$ (entries 8 and 9) were very good but the selectivity was poor. $t$-Butyraldehyde $\mathbf{2 j}$, most probably too hindered, was not very reactive and full conversion could not be obtained. Finally, the two ketones $\mathbf{2 k}$ and $\mathbf{2 1}$ which were tried in this reaction were unreactive. The HWE reaction of ketones for the synthesis of tetra-substituted alkenes is a more demanding process due to the steric hindrance involved between the two reactants, especially in the present study for the preparation of dehydro amino esters. In solution in the presence of sodium hydride, as stated by Schmidt et al., ${ }^{22 c}$ ketones are unreactive unless activated. Better results were obtained with DBU. ${ }^{22 a}$ In the ball-mill, only di- and tri-substituted olefins were synthesized using the Wittig reaction. ${ }^{12}$ The carbonate bases used in this study are probably not adapted to less reactive electrophiles.

In conclusion, the Horner-Wadsworth-Emmons reaction could be performed in the absence of solvent in a ball-mill. This represents a practical method for the preparation of Boc-protected unsaturated amino esters, with excellent yield and selectivity in many cases, making use of mild and inexpensive conditions. Further work to scale up this reaction is in progress. 
Table 2

Synthesis of amino esters in a ball-mill<smiles>[R]C([R])=C(N[R6](=O)[O-])C(=O)OC</smiles>

\begin{tabular}{|c|c|c|c|c|c|c|c|}
\hline Entry & Electrophile & Physical state $\mathrm{mp}\left({ }^{\circ} \mathrm{C}\right)$ & Base & Conversion (\%) & Product & Yield (\%) & $Z / E$ ratio \\
\hline 1 & & Solid 44-48 & $\mathrm{Cs}_{2} \mathrm{CO}_{3}$ & 100 & $3 a$ & 95 & $100 / 0$ \\
\hline 2 & & Solid 16-19 & $\mathrm{K}_{2} \mathrm{CO}_{3}$ & 96 & $\mathbf{3 b}$ & 85 & $100 / 0$ \\
\hline 3 & & Liquid & $\mathrm{K}_{2} \mathrm{CO}_{3}$ & 100 & $3 c$ & 88 & $100 / 0$ \\
\hline 4 & & Liquid & $\mathrm{K}_{2} \mathrm{CO}_{3}$ & 100 & 3d & 82 & $100 / 0$ \\
\hline 5 & & Liquid & $\mathrm{Cs}_{2} \mathrm{CO}_{3}$ & 100 & $3 e$ & 89 & $100 / 0$ \\
\hline 6 & & Liquid & $\mathrm{K}_{2} \mathrm{CO}_{3}$ & 100 & 3f & 76 & $82 / 18$ \\
\hline 7 & & Liquid & $\mathrm{K}_{2} \mathrm{CO}_{3}$ & 100 & $3 g$ & 80 & $100 / 0$ \\
\hline 8 & & Liquid & $\mathrm{K}_{2} \mathrm{CO}_{3}$ & 100 & $3 h$ & 61 & $66 / 44$ \\
\hline 9 & & Liquid & $\mathrm{K}_{2} \mathrm{CO}_{3}$ & 100 & $3 \mathbf{i}$ & 90 & $61 / 39$ \\
\hline 10 & & Liquid & $\mathrm{K}_{2} \mathrm{CO}_{3}$ & 35 & $3 \mathbf{j}$ & n.d. & $100 / 0$ \\
\hline 11 & & Solid & $\mathrm{K}_{2} \mathrm{CO}_{3}$ & 0 & $3 k$ & 0 & - \\
\hline 12 & O & Liquid & $\mathrm{K}_{2} \mathrm{CO}_{3}$ & 0 & 31 & 0 & - \\
\hline
\end{tabular}

\section{Acknowledgments}

We thank the MESR, the CNRS and Idenix Pharmaceuticals (fellowship to A.B.) for their financial support.

\section{References and notes}

1. Kaupp, G.; Naimi-Jamal, M. R.; Ren, H.; Zoz, H. In Technologies Based on Selfpropagating and Mechanochemical Reactions for Environmental Protection; Cao, G., Delogu, F., Orrù, R., Eds.; Research Signpost: Kerala, 2003; pp 83-100.

2. (a) Kipp, S.; Sepelàk, V.; Becker, K. D. Chem. Unserer Zeit 2005, 39, 384-392; (b) Garay, A. L.; Pichon, A.; James, S. L. Chem. Soc. Rev. 2007, 36, 846-855.

3. Kaupp, G. Top. Curr. Chem. 2005, 254, 95-183.

4. (a) Rodrìguez, B.; Bruckmann, A.; Rantanen, T.; Bolm, C. Adv. Synth. Catal. 2007, 349, 2213-2233; (b) Bruckmann, A.; Krebs, A.; Bolm, C. Green Chem. 2008, 10, 1131-1141.

5. Colacino, E.; Nun, P.; Colacino, F. M.; Martinez, J.; Lamaty, F. Tetrahedron 2008, $64,5569-5576$.
6. Komatsu, K. Top. Curr. Chem. 2005, 254, 185-206.

7. Zhang, Z.; Gao, J.; Xia, J.-J.; Wang, G.-W. Org. Biomol. Chem. 2005, 3, 16171619.

8. Kaupp, G.; Naimi-Jamal, M. R.; Stepanenko, V. Chem. Eur. J. 2003, 9, 41564160.

9. Kaupp, G.; Naimi-Jamal, M. R.; Schmeyers, J. Tetrahedron 2003, 59, 3753-3760.

10. Raston, C. L.; Scott, J. L. Green Chem. 2000, 49-52.

11. Rodrìguez, B.; Bruckmann, A.; Bolm, C. Chem. Eur. J. 2007, 13, 4710-4722.

12. Balema, V. P.; Wiench, J. W.; Pruski, M.; Pecharsky, V. K. J. Am. Chem. Soc. 2002, $124,6244-6245$.

13. Rasmussen, M. O.; Axelsson, O.; Tanner, D. Synth. Commun. 1997, 27, 40274030 .

14. (a) Tullberg, E.; Peters, D.; Frejd, T. J. Organomet. Chem. 2004, 689, 3778-3781; (b) Tullberg, E.; Schacher, F.; Peters, D.; Frejd, T. Synthesis 2006, 1183-1189.

15. (a) Bernhardt, F.; Trotzki, R.; Szuppa, T.; Stolle, A.; Ondruschka, B. Beilstein J. Org. Chem. 2010, 6; (b) Polshettiwar, V.; Varma, R. S. Green Chem. 2009, 275292; (c) Schneider, F.; Ondruschka, B. ChemSusChem 2008, 1, 622-625.

16. (a) Thorwirth, R.; Stolle, A.; Ondruschka, B. Green Chem. 2010, 985-991; (b) Fulmer, D. A.; Shearouse, W. C.; Medonza, S. T.; Mack, J. Green Chem. 2009, 1821-1825. 
17. Declerck, V.; Nun, P.; Martinez, J.; Lamaty, F. Angew. Chem., Int. Ed. 2009, 48, 9318-9321.

18. Vedejs, E.; Peterson, M. J.. In Advances in Carbanion Chemistry; Snieckus, V., Ed.; JAI Press Inc.: Greenwich, London, 1996; Vol. 2, pp 1-85.

19. Maryanoff, B. E.; Reitz, A. B. Chem. Rev. 1989, 89, 863-927.

20. (a) Sauvagnat, B.; Lamaty, F.; Lazaro, R.; Martinez, J. Tetrahedron Lett. 2000, 41 6371-6375; (b) Sauvagnat, B.; Lamaty, F.; Lazaro, R.; Martinez, J. Tetrahedron 2001, 57, 9711-9718; (c) Varray, S.; Lazaro, R.; Martinez, J.; Lamaty, F. Eur. J. Org. Chem. 2002, 2308-2316; (d) Varray, S.; Lazaro, R.; Martinez, J.; Lamaty, F. Organometallics 2003, 22, 2426-2435; (e) Lenda, F.; Guenoun, F.; Tazi, B.; Ben Larbi, N.; Martinez, J.; Lamaty, F. Tetrahedron Lett. 2004, 45, 8905-8907; (f) Declerck, V.: Ribière, P.: Nédellec, Y.; Allouchi, H.; Martinez, J.: Lamaty, F. Eur. J. Org. Chem. 2007, 201-208; (g) Declerck, V.; Allouchi, H.; Martinez, J.; Lamaty, F. J. Org. Chem. 2007, 72. 1518-152; (h) Declerck, V.; Martinez, J.; Lamaty, F. J. Org. Chem. 2009, 74, 2004-2007.

21. For an isolated example of HWE in a mortar: Yang, J. X.; Tao, X. T.; Yuan, C. X.; Yan, Y. X.; Wang, L.; Liu, Z.; Ren, Y.; Jiang, M. H. J. Am. Chem. Soc. 2005, 127, 3278-3279.

22. (a) Schmidt, U.; Griesser, H.; Leitenberger, V.; Lieberknecht, A.; Mangold, R.; Meyer, R.; Riedl, B. Synthesis 1992, 487-490; (b) Schmidt, U.; Lieberknecht, A.; Wild, J. Synthesis 1988, 159-172; (c) Schmidt, U.; Lieberknecht, A.; Wild, J. Synthesis 1984, 53-60.
23. (a) Ando, K.; Yamada, K. Tetrahedron Lett. 2010, 51, 3297-3299; (b) Ranoux, A.; Lemiegre, L.; Benoit, M.; Guegan, J. P.; Benvegnu, T. Eur. J. Org. Chem. 2010, 7, 1314-1323; (c) Jin, Y. Z.; Yasuda, N.; Inanaga, J. Green Chem. 2002, 4, 498500.

24. All new compounds were characterized by ${ }^{1} \mathrm{H}$ and ${ }^{13} \mathrm{C} N M R$, mass spectrometry, and high resolution mass spectrometry.

25. Procedure for the preparation of (Z)-methyl 2-[(tert-butoxycarbonyl)amino]-3(3,5-dimethoxyphenyl)acrylate 3a: methyl 2-[(tert-butoxycarbonyl)amino] -2-(dimethoxyphosphoryl)acetate ( $157 \mathrm{mg}, 0.53 \mathrm{mmol}$ ), 3,5-dimethoxybenzaldehyde ( $80 \mathrm{mg}, 0.48 \mathrm{mmol}$ ) and cesium carbonate ( $314 \mathrm{mg}, 0.96 \mathrm{mmol}$ ) were introduced in a $12 \mathrm{~mL}$ grinding jar with five stainless steel balls $(7 \mathrm{~mm}$ diameter). The grinding jar was placed in a planetary ball-mill and stirred at $550 \mathrm{rpm}$ during $7 \mathrm{~h}$. EtOAc was added in the jar and the mixture was washed with water, dried over $\mathrm{MgSO}_{4}$, concentrated under vacuo. The residue was filtered on a silica gel pad (eluent: cyclohexane/EtOAc, 1:1) to afford $165 \mathrm{mg}$ of the titled compound $(100 \%)$ as a white powder: mp $108-109{ }^{\circ} \mathrm{C} ;{ }^{1} \mathrm{H}$ NMR $\left(\mathrm{CDCl}_{3}, \mathrm{Me}_{4} \mathrm{Si}\right) \delta 1.30$ (br s, $\left.9 \mathrm{H}, \mathrm{C}\left(\mathrm{CH}_{3}\right)_{3}\right), 3.72(\mathrm{~s}, 6 \mathrm{H}, 2 \times \mathrm{OMe}), 3.95(\mathrm{~s}, 3 \mathrm{H}$, OMe), $6.37(\mathrm{t}, J=2.2 \mathrm{~Hz}, 1 \mathrm{H}, \mathrm{CH}), 6.63(\mathrm{~d}, J=2.0 \mathrm{~Hz}, 2 \mathrm{H}, 2 \times \mathrm{CH}), 7.09(1 \mathrm{H}, \mathrm{s}$, $\mathrm{CH}) .{ }^{13} \mathrm{C} \mathrm{NMR}\left(\mathrm{CDCl}_{3}, \mathrm{Me}_{4} \mathrm{Si}\right) \delta 28.10\left(\mathrm{C}\left(\mathrm{CH}_{3}\right)_{3}\right), 52.62\left(\mathrm{OCH}_{3}\right), 55.32\left(2 \mathrm{CCH}_{3}\right)$, $81.02(\mathrm{C}), 101.67(\mathrm{CH}), 107.46(2 \mathrm{CH}), 125.18(\mathrm{CH}), 129.76(\mathrm{C}), 135.76(\mathrm{C})$ $152.74(C=0), 160.66(2 C), 165.96(C=0)$; high resolution MS calcd for $\mathrm{C}_{17} \mathrm{H}_{24} \mathrm{NO}_{6}$ : 338.1604. Found: $338.1599[\mathrm{M}+\mathrm{H}]^{+}$. 